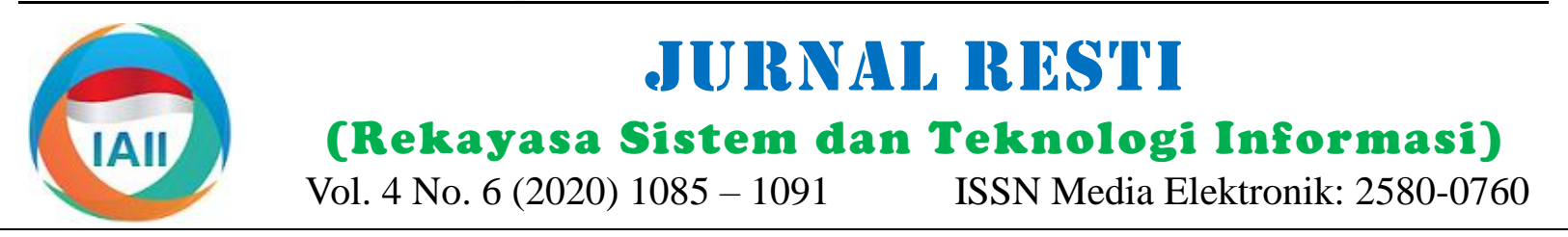

\title{
Implementasi JWT pada Aplikasi Presensi dengan Validasi Fingerprint, Geotagging dan Device Checker
}

\author{
Arief Umarjati ${ }^{1}$, Arief Wibowo ${ }^{2}$ \\ ${ }^{12}$ Teknik Informatika, Fakultas Teknologi Informasi, Universitas Budi Luhur \\ 12ariefumarjati@gmail.com*, 2arief.wibowo@budiluhur.ac.id
}

\begin{abstract}
During the Covid-19 pandemic the government implement the imposition of Large-Scale Social Restrictions (PSBB). This PSBB also has an impact on companies in Jabodetabek including PT Akses Digital Indonesia. In order to comply with regulations given by the government, PT Akses Digital Indonesia has implemented a Work From Home (WFH) policy for its employees. During the implementation of the WFH policy, had difficulty monitoring the performance of its employees. Attendance is one measure of the level of performance, especially employee discipline. Based on the identification of the problem, an employee presence web service application is needed. Of course, this application should be as effective as conventional fingerprint machines in offices. This application is accompanied by a validation feature using geotagging, fingerprint and device checkers to minimize fraud when employees make attendance. This study implements the RESTful API security feature on web services using JSON Web Token (JWT) based on the HMAC SHA-256 algorithm. All implementation stages are tested using the Black Box method and show that JWT can secure the authentication process and secure data. The validation feature is able to provide attendance data with an accuracy of 90,9\%.
\end{abstract}

Keywords: Attendance, Web Service, Fingerprint, Geotagging, JSON Web Token

\begin{abstract}
Abstrak
Pada masa pandemi Covid-19 pemerintah membuat beberapa peraturan untuk mencegah penyebaran penyakit berbahaya tersebut. Salah satu kebijakan yang diterapkan adalah pemberlakuan Pembatasan Sosial Berskala Besar (PSBB). PSBB ini juga memberi dampak terhadap perusahaan-perusahaan di Jabodetabek termasuk PT Akses Digital Indonesia. Demi mematuhi peraturan yang diberikan pemerintah, PT Akses Digital Indonesia melakukan kebijakan Work From Home (WFH) bagi karyawannya. Selama diberlakukannya kebijakan WFH, PT Akses Digital Indonesia mengalami kesulitan untuk mengawasi kinerja dari para karyawan. Presensi adalah salah satu tolak ukur dari tingkat kinerja, terutama kedisplinan karyawan. Berdasarkan identifikasi masalah tersebut, diperlukan aplikasi web service presensi karyawan. Tentunya aplikasi ini diharuskan sama efektifnya dengan mesin fingerprint konvensional yang berada di kantor. Aplikasi ini disertai fitur validasi menggunakan geotagging, fingerprint dan device checker untuk meminimalisir adanya kecurangan saat karyawan melakukan presensi. Penelitian ini mengimplementasikan fitur keamanan RESTful API pada web services dengan menggunakan JSON Web Token (JWT) berbasis algoritma HMAC SHA-256. Seluruh tahap implementasi diuji menggunakan metode Black Box dan menunjukkan bahwa JWT dapat mengamankan proses autentikasi, melakukan proses request \& response, dan pengamanan data. Selain itu, fitur validasi mampu memberikan data presensi dengan akurasi sebesar 90,9\%.
\end{abstract}

Kata kunci: Presensi, Web Service, Fingerprint, Geotagging, JSON Web Token

Diterima Redaksi : 19-11-2020 | Selesai Revisi : 13-12-2020 | Diterbitkan Online : 20-12-2020 


\section{Pendahuluan}

Karyawan merupakan ujung tombak dari perusahaan. Memiliki karyawan dengan kedisplinan yang baik adalah aset yang paling berharga bagi perusahaan. Untuk itu pengawasan terhadap kedisplinan karyawan sangat perlu dilakukan. Tingkat kedisiplinan dapat dilihat salah satunya dengan nilai presensi pegawai. Semakin baik presensi pegawai maka semakin tinggi pula kedisiplinan pegawai tersebut [1].

Permasalahan muncul semenjak pandemi Covid-19 mulai mewabah di Indonesia. Presiden Indonesia Joko Widodo dalam pidatonya mengintruksikan untuk masyarakat Indonesia mengurangi kegiatan di luar rumah yang tidak penting. Termasuk menerapkan sistem kerja Work From Home (WFH) [2]. Demi mematuhi kebijakan tersebut, PT Akses Digital Indonesia juga memberlakukan WFH kepada seluruh karyawannya.

Presensi karyawan sangat penting untuk karyawan PT Akses Digital karena presensi masuk dalam salah satu parameter dalam penilaian KPI (Key Performance Indicator) yang dimiliki masing-masing karyawan setiap bulannya. Sebelumnya pencatatan presensi karyawan di kantor menggunakan mesin presensi konvensional. Tapi semenjak WFH pencatatan presensi karyawan menjadi tidak teratur dan kurang dapat dipertanggungjawabkan, dikarenakan perbedaan lokasi dan kurangnya pengawasan secara langsung oleh kantor. Sehingga tidak diketahui apakah benar karyawan sedang berada dirumah atau tidak. Hal tersebut berpengaruh pada kebijakan PT Akses Digital bahwa kegiatan WFH itu bukan hanya berkerja dari rumah tapi juga menjaga kesehatan karyawan itu sendiri agar terhindar dari Covid-19 yang dapat mengganggu kinerjanya saat melakukan pekerjaan kantor. Masalah utamanya yaitu bagaimana cara menerapkan pengawasan presensi karyawan dengan fasilitas yang sama seperti mesin fingerprint yang berada di kantor selama WFH dilakukan serta pengawasan lokasi karyawan juga diperlukan untuk memastikan bahwa karyawan benar berada dirumah saat jam kerja WFH.

Solusi yang diberikan dari penelitian ini adalah penggunaan Aplikasi Presensi Karyawan yang dapat memberikan data check-in dan check-out kehadiran karyawan tanpa terkendala perbedaan lokasi serta dapat mengawasi karyawan bahwa karyawan benar berada di lokasi WFH yaitu di rumahnya. Penggunaan perangkat aplikasi juga secara simultan berpengaruh positif dan signifikan terhadap disiplin pegawai [3]. Data tersebut langsung terkirim ke server dan dapat dilihat langsung oleh admin. Aplikasi ini dibangun dengan teknologi web service berbasis Restful, sehingga dapat melakukan pertukaran dengan dengan aplikasi mobile android.

Web service adalah antarmuka yang menyediakan kumpulan operasi yang dapat diakses oleh jaringan internet [4]. Web Service digunakan untuk suatu fasilitas yang disediakan oleh suatu website untuk menyediakan layanan dalam bentuk informasi kepada sistem yang lainnya, sehingga sistem lain dapat berinteraksi dengan sistem tersebut yang melalui layanan-layanan (service). Web Service menyimpan data informasi dalam format standar seperti HTTP, XML, dan JSON [5].

Android adalah sistem operasi mobile yang saat ini paling populer. Tercatat per November 2020 pengguna Android di Indonesia sebesar 91.5\% [6]. Dan pengguna Android di PT Akses Digital Indonesia sebesar 100\%. Sehingga pengimplementasian aplikasi android ini sudah sangat tepat. Android juga menyediakan beragam fitur yang dapat mendukung dalam pengembangan aplikasi di penelitian ini, seperti fitur GPS dan Fingerprint [7].

Penelitian ini bertujuan untuk mengimplementasikan metode keamanan menggunakan JSON Web Token (JWT) pada web service di bagian autentikasi sistem. Studi ini juga mengimplementasikan fitur geotagging, fingerprint, dan device checker yang diharapkan dapat menjadi solusi untuk keamanan dan keefektifan data pada Aplikasi Presensi Karyawan di PT Akses Digital Indonesia dan semoga dapat menyempurnakan penelitian sebelumnya.

\section{Metode Penelitian}

Metode penelitian yang dilakukan pada studi ini menggunakan metode prototipe. Prototipe adalah versi awal dari sistem perangkat lunak yang digunakan untuk mendemonstrasikan konsep, mencoba opsi desain, dan mencari tahu lebih banyak tentang masalah dan kemungkinan solusinya. Pengembangan prototipe yang cepat dan berulang sangat penting agar biaya dapat dikendalikan dan pemangku kepentingan sistem dapat bereksperimen dengan prototipe di awal proses perangkat lunak [8]. Dengan 4 tahapan yaitu Problem Statement and Literature Review (Pernyataan Masalah dan Tinjauan Pustaka), Design Prototype (Desain Prototipe), Build Prototype (Membangun Prototipe), Blackbox Testing (Pengujian Blackbox).

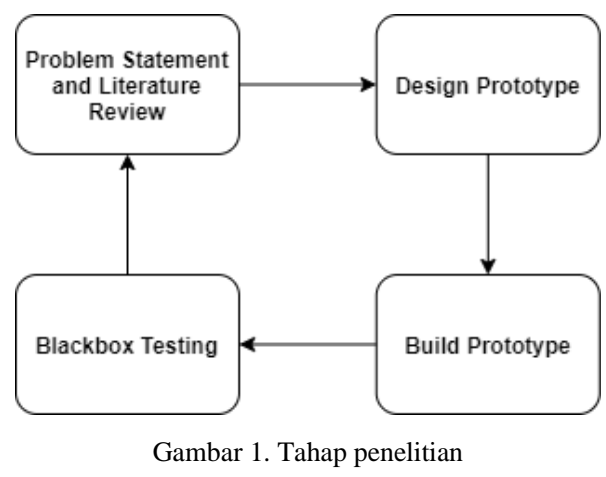

\subsection{Problem Statement and Literature Review}

Tahap pertama, penulis menggali masalah dan solusi yang dibutuhkan untuk penelitian ini dengan cara mengumpulkan semua data karyawan dan data resourse

Jurnal RESTI (Rekayasa Sistem dan Teknologi Informasi) Vol. 4 No. 6 (2020) 1085 - 1091 
yang dimiliki oleh para karyawan di PT Akses Digital Indonesia.

Masalah yang ditemukan adalah PT Akses Digital Indonesia membutuhkan suatu alat bantu untuk mencatat presensi karyawan yang dapat digunakan selama Work From Home dengan fasilitas yang sama atau lebih dari mesin presensi konventional yang hanya bisa digunakan saat datang ke kantor. Penulis mendapatkan data bahwa 100\% karyawan PT Akses Digital Indonesia menggunakan smartphone dengan basis android dan memiliki fitur sensor fingerprint dan GPS.

Dengan data dan informasi yang telah didapatkan sebelumnya. Maka solusi yang dapat diberikan adalah pembuatan Aplikasi Presensi Karyawan berbasis web service dengan client web dari sisi admin dan client mobile android dari sisi karyawan. Komunikasi data antar client akan menggunakan metode RESTful API dan JSON Web Token sebagai pengamannya.

Pada penelitian sebelumnya sudah banyak yang membangun web service aplikasi presensi dengan komunikasi RESTful API. Salah satunya adalah penelitian membahas algoritma Point Clipping pada aplikasi presensi karyawan [9]. Akan tetapi penelitian tersebut masih belum menerapkan keamanan dalam implementasi RESTful API. Sehingga kemungkinan adanya request yang dilakukan dari luar lingkungan web service dan tidak mempunyai ijin akan mudah masuk ke dalam internal system [10].

Di penelitian lainnya, penerapan fingerprint menggunakan android memang cukup efektif untuk memvalidasi kehadiran [11]. Akan tetapi setiap perangkat android dapat didaftarkan hingga 5 data biometric fingerprint. Sehingga kemungkinan user satu mengakses aplikasi user lainnya itu sangat besar.

Untuk pencegahan adanya kecurangan dalam melakukan presensi oleh karyawan, pada penilitian ini akan menerapkan 3 validasi, yaitu fingerprint, geotagging, dan device checker.

Validasi fingerprint digunakan untuk memastikan bahwa tidak sembarang user dapat melakukan check in dan check out presensi. Validasi geotagging digunakan untuk memastikan bahwa user berada dilingkungan Work From Home, yaitu dirumahnya. Validasi device checker digunakan untuk memastikan bahwa user hanya melakukan check in dan check out presensi melalui device miliki user itu sendiri.

\subsection{Design Prototype}

Tahap kedua, yaitu merancang Aplikasi Presensi dengan 2 client dan 1 internal sistem untuk bagian backend. Desain sistem akan terlihat seperti Gambar 2.

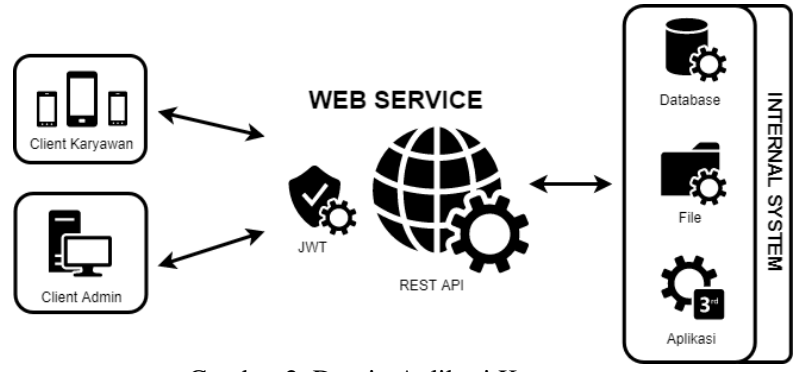

Gambar 2. Desain Aplikasi Karyawan

Client Karyawan akan dibangun dengan platform berbasis Android dengan menggunakan bahasa dart dan framework flutter. Di aplikasi ini karyawan akan melakukan check in dan check out presensi.

Client Admin akan dibangun dengan platform berbasis web dengan menggunakan bahasa javascript dan framework vue.js. Di aplikasi ini admin dapat mengawasi dan mengolah data karyawan dan presensi.

Bagian internal sistem akan dibangun dengan bahasa javascript dan framework Express.js. Di aplikasi ini akan mengimplementasikan JSON Web Token, berhubungan dengan database, dan menangani request dan response dari client. Komunikasinya akan menggunakan metode RESTful API.

\subsection{Build Prototype}

Tahap ketiga, dilakukan yaitu pengimplementasian RESTful Web Service dan JSON Web Token di Express JS, dimulai dengan memasang jsonwebtoken package dengan Node Package Manager (NPM) .

\section{NPM Command}

$\$ \mathrm{npm}$ instal7 jsonwebtoken

Proses selanjutnya adalah mendeklarasikan package di dalam file dimana request login diproses. Dalam penelitian ini jsonwebtoken package dideklarasikan di authController.js dengan menambahkan baris code seperti dibawah.

$\frac{\overline{\text { Declare JWT }}}{\text { const jwt }=\text { require ("jsonwebtoken"); }}$

Menambahkan JWT KEY di file .env. JWT KEY ini akan digunakan saat membuat token.

$\frac{\text { JWT KEY }}{\text { JWT_KEY=secret }}$

Pemasangan JSON Web Token pada aplikasi telah selesai. Tahap terakhir adalah memberikan token kepada user setiap kali user melakukan login.

\begin{tabular}{l}
\hline Declare JWT \\
\hline const token $=$ jwt.sign(\{username: \\
user.username, role : User.role\}, \\
process.env.JWT_KEY, \{algorithm: 'HS256\});
\end{tabular}

Selanjutnya adalah pengujian request post dengan route login melalui client web admin. Dengan input request username dan password seperti pada Gambar 3. 


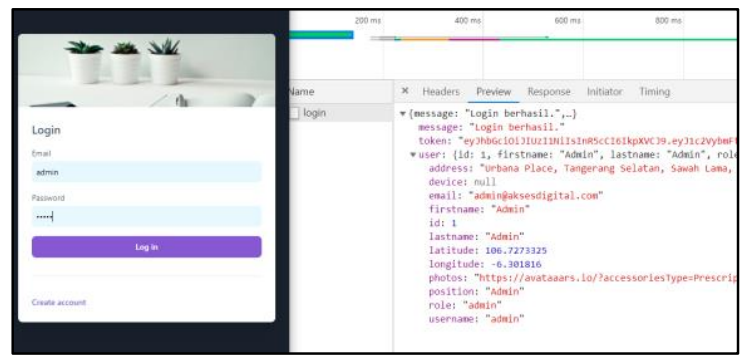

Gambar 3. Request dan Response Route Login

Saat request login terkirim server web service akan melakukan pengecekan ke database dan memeriksa apakah username yang di-input ada. Jika tidak ditemukan maka server web service akan mengirimkan response error "User tidak ditemukan" dan web service tidak akan memberikan token. Tapi jika username ditemukan di database, selanjutnya web service akan mencocokan password yang dikirim dengan username miliki di database. Jika password cocok selanjutnya server web service akan mengirimkan response data user dan token seperti di gambar 3.

Response yang didapatkan pada gambar 3 sukses dengan response code 200, response time $136 \mathrm{~ms}$, dan ukuran $1.0 \mathrm{~kb}$. Selanjutnya token akan disimpan oleh client dan akan digunakan sebagai claim bahwa user tersebut dapat melakukan request lain. Setiap user ingin melakukan request, user tersebut juga harus mengirimkan token melalui header request dengan key "Authorization" dan value "Bearer Token".

Header Authorization yang dikirimkan oleh user setiap kali melakukan request selanjutnya akan diperiksa oleh middleware di server web service. Web service akan men-verify token yang dikirim dan akan dicocokan oleh data user di database. Jika data user tidak cocok maka request akan ditolak oleh server web service dan mendapatkan response "Unauthorized Access API".

$\frac{\text { Verify TOKEN }}{\text { jwt.verify(token, process.env.JWT_KEY); }}$

Pengujian selanjutnya yang akan dilakukan adalah melakukan request lain pada route lemployee dengan menggunakan token dan tanpa menggunakan token untuk menguji keamanan dari JSON WEB TOKEN.

Pada Gambar 4 request route lemployee mengunakan header Authorization dengan Bearer Token mendapatkan response code 200, response message "Sukses" dan data employee, response time $153 \mathrm{~ms}$, dan ukuran response sebesar 924b.

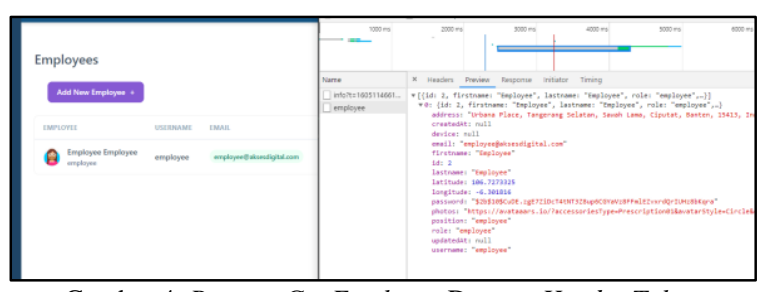

Gambar 4. Request Get Employee Dengan Header Token
Sedangkan pada Gambar 5 request route employee tanpa mengunakan header Authorization dengan Bearer Token mendapatkan response code error 401 Unauthorized dan response message "Unanthorized Access API'.

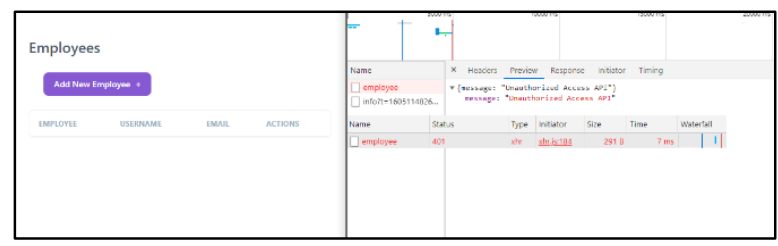

Gambar 5. Request Get Employee Tanpa Header Token

Selanjutnya dilakukan Implementasi validasi pada aplikasi presensi saat melakukan check in dan check out. Dari sisi internal system / backend kita sudah memberikan keamanan dalam proses komunikasi data RESTful API dengan menggunakan JSON Web Token. Akan tetapi dari segi fungsionalnya kita perlu juga menjaga agar data yang diinput itu merupakan data yang jujur dan sah.

Aplikasi akan meminta sidik jari karyawan saat melakukan check in maupun check out presensi [12]. Saat sidik jari disentuhkan ke sensor fingerprint handphone, aplikasi akan mengambil data lokasi dan nama handphone karyawan, sehingga karyawan tidak dapat melakukan kecurangan saat berada di luar lokasi WFH atau menggunakan device android yang lain. Sehingga logikanya akan tergambar seperti dibawah.

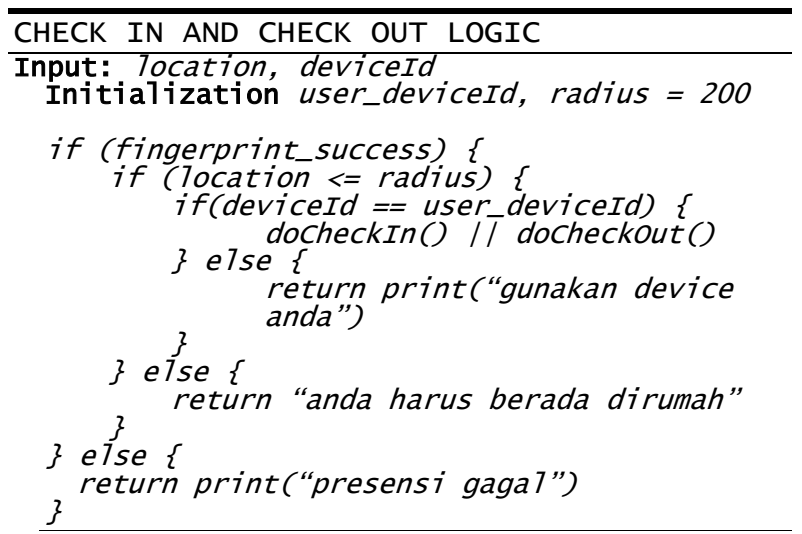

Aplikasi presensi sisi karyawan akan berbasis android dengan menggunakan bahasa pemrograman dart dan framework Flutter. Untuk dapat menggunakan 3 validasi yang disebutkan sebelumnya maka kita perlu memasang package geolocator, fingerprint dan device info.

\begin{tabular}{l}
\hline ADD PACKAGE \\
\hline Dependencies: \\
7ocal_auth: $10.6 .3+2$ \\
geolocator: 16.0 .0 \\
device_info: 11.0 .0
\end{tabular}

Sesuai logic yang tertulis sebelumnya, yang pertama perlu dilakukan adalah meminta user untuk melakukan 
fingerprint. Jalankan function dari package local_auth. Setiap kali user menekan tombol check in atau check out akan muncul pop up untuk meminta fingerprint seperti Gambar 6.

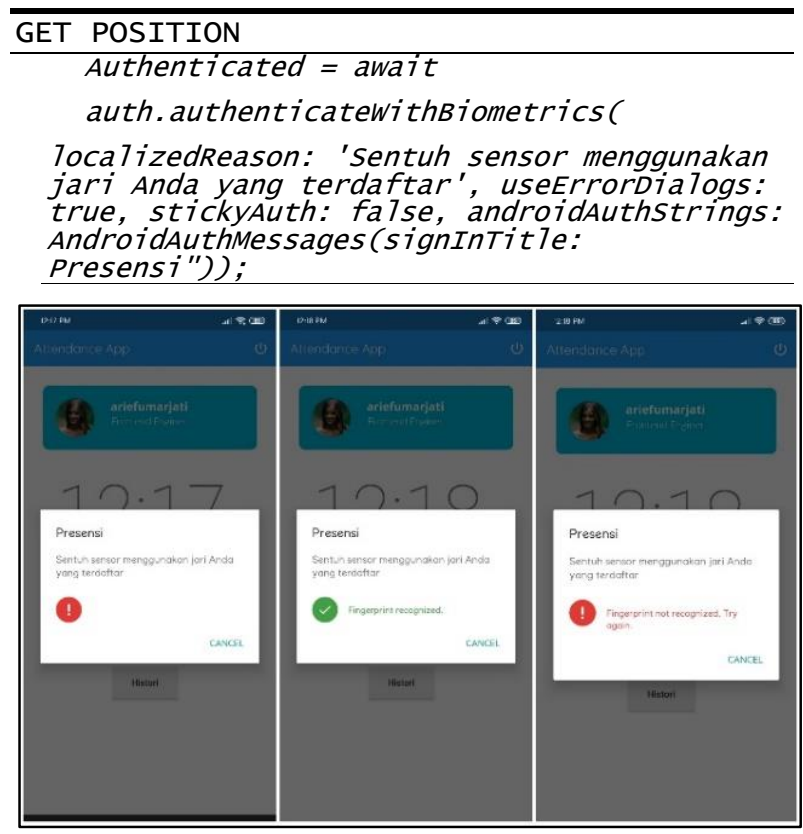

Gambar 6. Pop Up Fingerprint (kiri), fingerprint dikenali (tengah), fingerprint tidak dikenali (kanan)

Selanjutnya jika fingerprint dikenali maka aplikasi akan mengakses lokasi user saat ini. Jalankan function dari package geolocator untuk mengambil data latitude dan longitude. Setelah itu kita harus mengukur jarak lokasi user saat ini dengan lokasi rumah user. Lokasi rumah user didapatkan dari data user di database. Jalankan function untuk mengukur jarak.

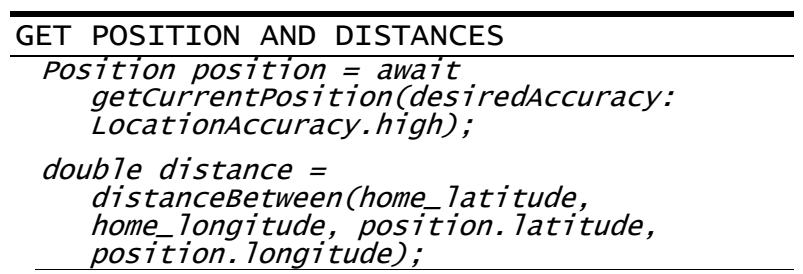

Jika lokasi sesuai dalam jangkauan radius rumah user maka aplikasi akan memindai data device dan mengambil data AndroidId untuk melakukan request post check in atau check out menggunakan function package device_info.

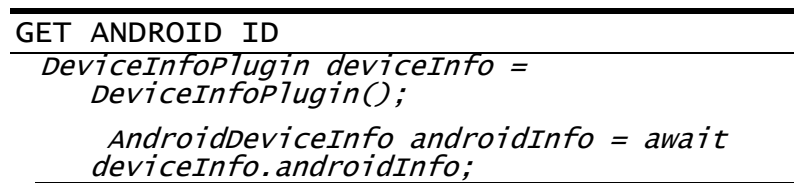

Request yang terkirim ke server web service selanjutnya diolah dan akan dicek apakah menggunakan device yang sama dengan device yang terdaftar di data user. Jika data device yang dikirim sesuai maka presensi berhasil, sedangkan jika data device tidak sesuai maka presensi gagal dan akan memunculkan keterangan "Anda tidak menggunakan device Anda" seperti pada Gambar 7.

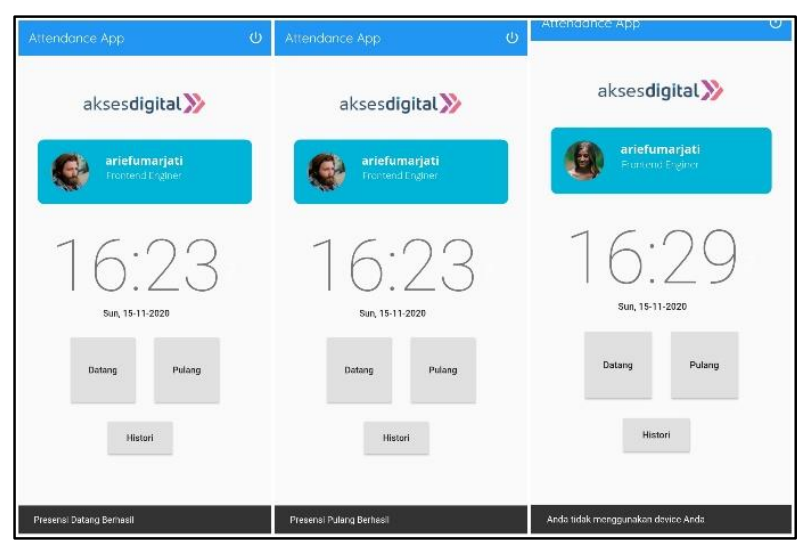

Gambar 7. Presensi Datang Berhasil (kiri), Presensi Pulang Berhasil (tengah), Presensi Gagal (kanan)

Selanjutnya user dapat melihat history presensi dengan menekan tombol "History" seperti pada Gambar 8.

\begin{tabular}{|c|c|c|c|}
\hline \multicolumn{3}{|l|}{ 12:20 AM } & \multirow{2}{*}{$A=\mathbb{D}$} \\
\hline \multicolumn{3}{|c|}{ Attendances History } & \\
\hline Date & Time & Type & Condition \\
\hline $14-11-2020$ & OB:16 & Datang & Tepat \\
\hline $14-11-2020$ & 11:13 & Datang & Terlambat \\
\hline $14-11-2020$ & $11: 43$ & Datang & Terlambat \\
\hline $14 \cdot 11-2020$ & $11: 43$ & Datang & Terlambat \\
\hline $14-11-2020$ & $11: 49$ & Datang & Terlambat \\
\hline $14-11-2020$ & $11: 51$ & Datang & Terlambat \\
\hline $14-11-2020$ & $11: 51$ & Datang & Terlambat \\
\hline $14-11-2020$ & 18:38 & Datang & Terlambat \\
\hline $14-11-2020$ & 21:11 & Datang & Terlambat \\
\hline $14-11-2020$ & 21:11 & Pulang & Lebih Awal \\
\hline $15-11-2020$ & $12: 17$ & Datang & Terlambat \\
\hline $15-11-2020$ & 12:17 & Datang & Terlambat \\
\hline $15-11-2020$ & $12: 17$ & Datang & Terlambat \\
\hline $15-11-2020$ & $12: 17$ & Datang & Terlambat \\
\hline
\end{tabular}

Gambar 8. History_Presensi

\section{Hasil dan Pembahasan}

Di tahap akhir ini adalah tahap dimana perlu dilakukannya pengujian dan evaluasi. Pengujian dan evaluasi ini perlu dilakukan untuk mengetahui bahwa 
aspek fungsionalitas dari web service ini sudah memenuhi kebutuhan, keamanan, dan keefektifan data. Metode pengujian menggunakan metode blackbox. Pengujian melibatkan 11 karyawan di PT Akses Digital dengan lokasi rumah yang berbeda-beda. Selanjutnya hasil pengujian dijelaskan pada Tabel 1.

Tabel 1. Tabel proses uji request dan response web service

\begin{tabular}{|c|c|c|c|c|}
\hline Services & Route & Method & Platform & $\begin{array}{l}\text { Tim } \\
e^{-1}\end{array}$ \\
\hline Register & /auth/register & POST & Web & $300 \mathrm{~ms}$ \\
\hline Login & /auth/login & POST & Web & $276 \mathrm{~ms}$ \\
\hline Edit Admin & $\begin{array}{l}\text { /auth/admin/: } \\
\text { id/edit }\end{array}$ & PUT & Web & $167 \mathrm{~ms}$ \\
\hline $\begin{array}{l}\text { Edit } \\
\text { Employee }\end{array}$ & $\begin{array}{l}\text { /employee/:i } \\
\text { d/edit }\end{array}$ & PUT & Web & $72 \mathrm{~ms}$ \\
\hline $\begin{array}{l}\text { List } \\
\text { Employee }\end{array}$ & /employee & GET & Web & $139 \mathrm{~ms}$ \\
\hline $\begin{array}{l}\text { Delete } \\
\text { Employee }\end{array}$ & $\begin{array}{l}\text { /employee/de } \\
\text { lete/:id }\end{array}$ & DELETE & Web & $80 \mathrm{~ms}$ \\
\hline Statistik & $\begin{array}{l}\text { /configuratio } \\
\text { n/dashboard }\end{array}$ & GET & Web & $193 \mathrm{~ms}$ \\
\hline $\begin{array}{l}\text { Configurati } \\
\text { on }\end{array}$ & $\begin{array}{l}\text { /configuratio } \\
\mathrm{n}\end{array}$ & GET & Web & $60 \mathrm{~ms}$ \\
\hline $\begin{array}{l}\text { Edit } \\
\text { Configurati } \\
\text { on }\end{array}$ & $\begin{array}{l}\text { /configuratio } \\
\text { n/edit }\end{array}$ & PUT & Web & $79 \mathrm{~ms}$ \\
\hline $\begin{array}{l}\text { List } \\
\text { Attendance }\end{array}$ & /attendance & GET & Web & $189 \mathrm{~ms}$ \\
\hline $\begin{array}{l}\text { List } \\
\text { employee } \\
\text { Attendance }\end{array}$ & $\begin{array}{l}\text { /attendance/:i } \\
\mathrm{d}\end{array}$ & GET & Android & $109 \mathrm{~ms}$ \\
\hline Presence & $\begin{array}{l}\text { /attendance/:i } \\
\mathrm{d} / \text { presence }\end{array}$ & POST & Android & $157 \mathrm{~ms}$ \\
\hline
\end{tabular}

Pada tabel 1 terdapat kolom dari nama services, route, method, platform, dan time. Dapat diketahui dari tabel tersebut bahwa seluruh layanan dari webservice berhasil diakses menggunakan route dan method yang tersedia. Serta dapat diakses dari platform yang berbeda. Dengan rata-rata kecepatan sebesar $151.75 \mathrm{~ms}$.

Selanjutnya adalah pengujian validasi. Pada gambar 9 adalah bentuk dari skenario pengujian validasi yang dilakukan. Validasi yang pertama dilakukan adalah validasi fingerprint, apabila sidik jari berhasil terbaca oleh sensor dan terdaftar maka sistem akan melakukan pengambilan data lokasi untuk memvalidasi lokasi, jika lokasi karyawan tidak lebih 200m selanjutnya sistem akan mengambil data Android ID milik karyawan. Lalu sistem akan membandingan Android ID milik karyawan dengan Android ID yang terdaftar pada database user. Jika Android ID sesuai maka karyawan berhasil melewati seluruh validasi dan presensinya sukses, sebaliknya jika tidak sesuai maka presensinya akan gagal.

Pada tabel 2 adalah hasil pengujian presensi dengan melewati validasi fingerprint, location, dan device checker. Keterangan untuk kolom U adalah username, FP adalah fingerprint, DL adalah distance location, dan Aid adalah androidId didapatkan dari package device_info. FP bernilai true apabila user berhasil melewati validasi fingerprint dengan cara menyentuhkan jari ke sensor fingerprint. DL didapatkan dengan membandingkan jarak antara lokasi user saat ini dengan lokasi rumah user yang sudah terdaftar di database user. DL terhitung sukses apabila lokasi karyawan berada pada radius toleransi yang diberikan PT Akses Digital Indonesia, yaitu sebesar 200m dari rumahnya. Aid akan bernilai true apabila user menggunakan device yang terdaftar di database user. Pada kolom Ket akan bernilai "sesuai" apabila kesalahan diakibatkan oleh kesalahan user, dan "tidak sesuai" apabila diakibatkan oleh kesalahan sistem aplikasi. Validasi FP, DL, dan Aid bersifat berurutan dan saling berkaitan. Jadi apabila salah satu validasi gagal maka validasi berikutnya juga ikut gagal.

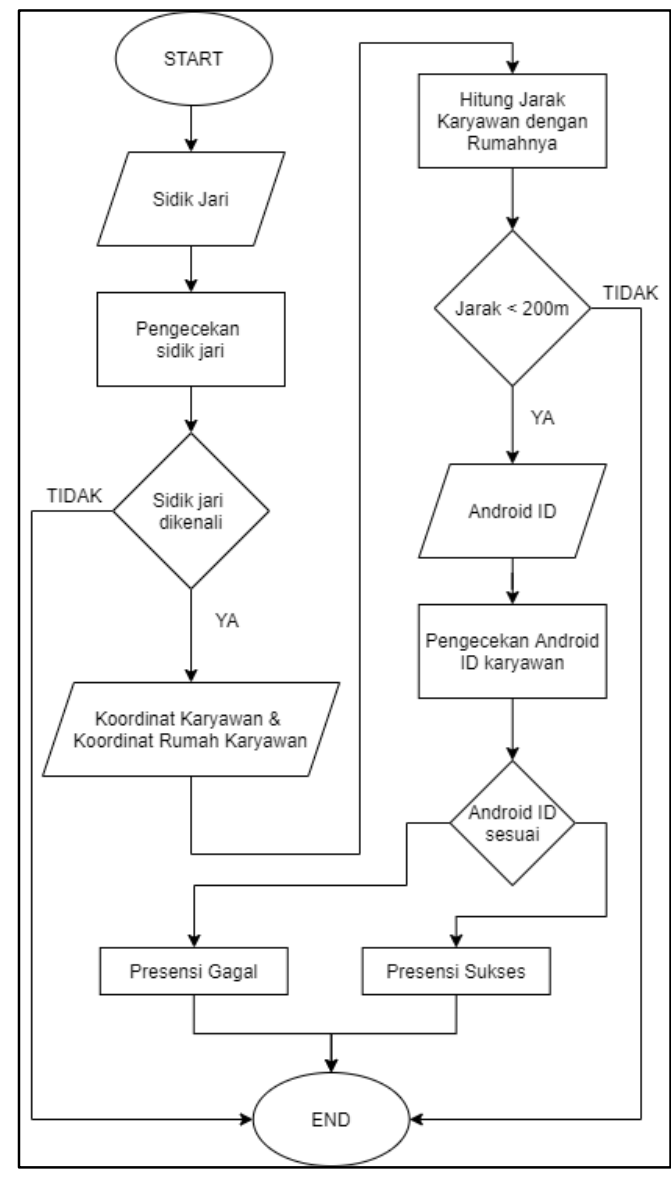

Gambar 9. Skenario Pengujian Validasi

Tabel 2. Tabel Hasil Pengujian Validasi

\begin{tabular}{lcccccc}
\hline \multicolumn{1}{c}{$\mathrm{U}$} & $\mathrm{FP}$ & $\mathrm{DL}$ & Aid & & \multicolumn{1}{c}{ Hasil } & Ket \\
\hline ariefumarj*** & true & $15 \mathrm{~m}$ & true & sukses & Sesuai \\
allyapu*** & true & $20 \mathrm{~m}$ & true & sukses & Sesuai \\
amandalaks*** & true & $116 \mathrm{~m}$ & true & sukses & Sesuai \\
topazab** & true & $150 \mathrm{~m}$ & true & sukses & Sesuai \\
rivaldisu**** & true & $17 \mathrm{~m}$ & true & sukses & Sesuai \\
fannyely*** & false & - & - & gagal, & Sesuai \\
& & & & tangan & \\
& & & & berminyak & \\
fajara*** & true & $370 \mathrm{~m}$ & - & gagal, & Tidak \\
& & & & lokasi & sesuai
\end{tabular}




\begin{tabular}{|c|c|c|c|c|c|}
\hline & & & & $\begin{array}{l}\text { tidak } \\
\text { akurat }\end{array}$ & \\
\hline rezzaanug*** & true & $34 \mathrm{~m}$ & true & sukses & Sesuai \\
\hline ismunan*** & true & $55 \mathrm{~m}$ & true & sukses & Sesuai \\
\hline agungnue $* * *$ & true & $90 \mathrm{~m}$ & true & sukses & Sesuai \\
\hline dimasag*** & true & $9 m$ & false & $\begin{array}{l}\text { gagal, } \\
\text { pakai } \\
\text { device } \\
\text { lain }\end{array}$ & Sesuai \\
\hline
\end{tabular}

Dari Tabel 2 dapat diketahui bahwa validasi menggunakan fingerprint, geotagging, dan checking device dapat menghasilkan data dengan akurasi sebesar 90,9\%. Dengan 1 ketidaksesuaian data (dengan catatan kesalahan dari sistem) dan 10 data sesuai.

Tabel 3. Tabel Pengujian Fungsi Aplikasi

\begin{tabular}{clc}
\hline No & \multicolumn{1}{c}{ Nama Fungsi } & Hasil \\
\hline 1 & $\begin{array}{l}\text { Aplikasi berhasil berjalan pada sistem } \\
\text { web }\end{array}$ & Sukses \\
2 & $\begin{array}{l}\text { Aplikasi berhasil berjalan pada sistem } \\
\text { android }\end{array}$ & Sukses \\
3 & $\begin{array}{l}\text { Aplikasi berhasil melakukan request ke } \\
\text { web service }\end{array}$ & Sukses \\
& $\begin{array}{l}\text { Aplikasi berhasil mendapatkan response } \\
\text { dari web service }\end{array}$ & Sukses \\
& $\begin{array}{l}\text { Aplikasi berhasil mengambil data } \\
\text { fingerprint, lokasi, dan data device }\end{array}$ & Sukses \\
& & \\
\hline
\end{tabular}

Pada Tabel 3 dijelaskan bahwa seluruh fungsi yang terdapat pada web service ini berjalan dengan baik dan $100 \%$ berhasil sukses.

\section{Kesimpulan}

Berdasarkan hasil dari pengujian dan evaluasi yang telah dilakukan, Aplikasi Presensi dengan menggunakan 3 validasi (fingerprint, geotagging, dan device $i d$ ) ini sukses mengatasi masalah pengawasan kehadiran karyawan di PT Akses Digital Indonesia dengan tingkat kesuksesan sebesar 90.9\%. Dengan fitur yang hampir sama atau lebih dibandingkan dengan mesin fingerprint konvensional seperti yang beda di kantor karena data presensi dapat langsung diawasi oleh admin secara realtime tanpa harus mengambil data secara manual dari mesin fingerprint konvensional. Implementasi JSON Web Token pada web service di aplikasi ini juga mampu memberikan token sebagai validasi bahwa user yang melakukan login dari aplikasi client web admin maupun aplikasi client android karyawan itu merupakan user yang sah dan dapat melakukan request data ke server web service.

\section{Daftar Rujukan}

[1] E. Ilham, "Membangun Sistem Pengelolaan Presensi Untuk Meningkatkan Kedisiplinan Pegawai ( Studi Kasus: Pemda Sidoarjo )," Seminar, vol. 2007, no. Snati, pp. 1-5, 2007.

[2] A. Purwanto, "Studi eksplorasi Dampak WFH Terhadap Kinerja Guru," J. Educ. Psychol. Couns., vol. 2, no. 1, pp. 92100, 2020.

[3] R. Fadila and M. Septiana, "Pengaruh Penerapan Sistem
Absensi Finger Print Terhadap Disiplin Pegawai Pada Markas Komando Direktorat Pengamanan Badan Pengusahaan Batam," J. Appl. Bus. Adm., vol. 3, no. 1, pp. 53-63, 2019, doi 10.30871/jaba.v3i1.1287.

[4] E. Edy, F. Ferdiansyah, W. Pramusinto, and S. Waluyo, "Pengamanan Restful API menggunakan JWT untuk Aplikas Sales Order," J. RESTI (Rekayasa Sist. dan Teknol. Informasi), vol. 3, no. 2, pp. 106-112, 2019, doi: 10.29207/resti.v3i2.860.

[5] K. Gottschalk, S. Graham, H. Kreger, and J. Snell, "Introduction to Web services architecture," IBM Syst. J., vol 41, no. 2, pp. 170-177, 2002, doi: 10.1147/sj.412.0170.

[6] "Mobile Operating System Market Share Indonesia." [Online]. Available: https://gs.statcounter.com/os-marketshare/mobile/indonesia. [Accessed: 12-Nov-2020].

[7] H. N. Lengkong, A. A. E. Sinsuw, and A. S. . Lumenta, "Perancangan Penunjuk Rute Pada Kendaraan Pribadi Menggunakan Aplikasi Mobile GIS Berbasis Android Yang Terintegrasi Pada Google Maps," E-journal Tek. Elektro dan Komput., vol. 2015, no. 2015, pp. 18-25, 2015.

[8] I. Sommerville, Software Engineering. 2013.

[9] A. Rahmatulloh, R. Rianto, and M. Q. Shihab, "Point Clipping Algorithm on Employee Presence Application for Geolocation of Employee Position," Kinet. Game Technol. Inf. Syst. Comput. Network, Comput. Electron. Control, vol. 4, no. 4, pp. 345-356, 2019, doi: 10.22219/kinetik.v4i4.796.

[10] R. C. Rajagukguk, "Penggunaan Kriptografi pada JWT ( JSON Web Token ) dalam Implementasi Keamanan API," 2018.

[11] A. Sumarudin, W. Permana, A. Suheryadi, K. Maulana, and N. Ibrahim, "Penerapan Sistem Absensi Sekolah Menggunakan Fingerprint Terintegrasi Dengan Smartphone Android," J. Appl. Informatics Comput., vol. 3, no. 1, pp. 18-22, 2019, doi: 10.30871/jaic.v3i1.1051.

[12] N. A. Muhammad, "Pembuatan Aplikasi Presensi Perkuliahan Berbasis Fingerprint," J. Tek. POMITS, vol. 2, no. 3, pp. 465469, 2013. 